\title{
ANALISIS PENGARUH FAKTOR EKSTERNAL DAN INTERNAL PERBANKAN TERHADAP LIKUIDITAS PERBANKAN SYARIAH DI INDONESIA PERIODE JANUARI 2003 - OKTOBER 2015
}

\author{
Lina Nugraha Rani* \\ Universitas Airlangga
}

\begin{abstract}
Liquidity is the fulfillment of bank liabilities that must be considered in the Islamic banking operations and errors in the management of liquidity can cause loss of Islamic banking which have an impact on the decline for the profit sharing to deposits customers and shareholders of Islamic banking. This study was to investigate the influence of external factors (Economic Performance (EK), inflation (INF), the Global Financial Crisis (D07)) and internal (Non Performing Financing (NPF) and Rate of Return (Deposit) of banks to liquidity (FDR) of Sharia Banking in Indonesia. Data were collected on a monthly basis from January 2003 - October 2015 times series data are tested by unit root and cointegration using Eviews 6.1. to determine the relationship between the variables in the long run. Based on the results of cointegration tests indicate that in long term relationships, NPF and EK variables have a significant and negative influence on the FDR, RRD variables have significant and positive influence on the FDR while variable INF and D07 does not have a significant influence on the FDR. It can be concluded that the Islamic banking must pay attention to the increase in marketing of Islamic banking products to increase liquidity despite good economic conditions and lower financing problems to increase the liquidity of Islamic banking.
\end{abstract}

Keywords : FDR, Banking External and Internal Factors (Economic Performance, Inflation, Global Financial Crisis, NPF, Rate of Return (Deposit),

\begin{abstract}
Abstrak
Penelitian ini untuk mengetahui pengaruh faktor eksternal (Kinerja Ekonomi(EK), Inflasi (INF), Krisis Keuangan Global (D07)) dan internal (Non Performing Financing $(N P F)$ dan Tingkat Pengembalian Deposito (RRD) perbankan terhadap likuiditas (FDR) Perbankan Syariah di Indonesia. Data yang dikumpulkan secara bulanan dari Januari 2003 - Oktober 2015. Data tersebut diuji unit akarnya dan diuji kointegrasi dengan menggunakan Eviews 6.1. Berdasarkan hasil uji kointegrasi menunjukkan bahwa dalam hubungan jangka panjang : variabel EK dan NPF memiliki pengaruh secara signifikan dan negatif terhadap FDR, variabel RRD memiliki pengaruh secara signifikan dan positif terhadap FDR sedangkan variabel INF dan D07 tidak berpengaruh secara signifikan terhadap FDR. Perbankan Syariah harus memperhatikan peningkatan pemasaran produk untuk meningkatkan likuiditas sekalipun kondisi perekonomian bagus dan menurunkan tingkat pembiayaan bermasalah untuk meningkatkan likuiditas perbankan Syariah.
\end{abstract}

Kata Kunci : FDR, Banking External and Internal Factors (Economic Performance, Inflation, Global Financial Crisis, NPF, Rate of Return (Deposit),

\footnotetext{
Received: 21 Desember 2016; Accepted: 06 Januari 2017; Published: 17 Januari 2017

*Korespondensi: Program Studi Ekonomi Islam, Fakultas Ekonomi dan Bisnis,

Universitas Airlangga, Jl. Airlangga No.4 Surabaya 60286.

Email: linanugraha@feb.unair.ac.id
} 


\section{PENDAHULUAN}

Ketentuan umum operasional bank berdasarkan Undang - Undang Republik Indonesia Nomor 21 Tahun 2008, Tentang Perbankan Syariah, Pasal 1 ayat 2, dimana bank adalah badan usaha yang menghimpun dana dari masyarakat dalam bentuk Simpanan dan menyalurkannya kepada masyarakat dalam bentuk kredit dan/atau bentuk lainnya dalam rangka meningkatkan taraf hidup rakyat. Fungsi Bank Syariah juga diatur pada pasal 4, yaitu Bank Syariah dan UUS wajib menjalankan fungsi menghimpun dan menyalurkan dana masyarakat.

Keberlangsungan operasional Bank Syariah ditentukan pendapatan usaha yang diterima oleh bank. Pendapatan usaha atau laba Bank Syariah merupakan indikator keberhasilan operasional Bank Syariah. Pendapatan usaha atau laba Bank Syariah diperuntukkan terutama untuk para pemegang saham dan nasabah simpanan, yang telah memberikan dananya sebagai sumber dana Bank Syariah untuk dapat menyalurkan pembiayaan melalui beberapa skema akad pembiayaan. Pada umumnya skema akad pembiayaan bank syariah adalah musyarakah, mudharabah, murabahah, ijarah, qard dan Istishna' (Ridlwan, 2016).

Dalam rangka menghasilkan laba perusahaan yang optimal maka Bank Syariah harus dapat mengelola keseimbangan pada transaksi keuangan perusahan dari sisi Aktiva (Aset) dan Pasiva (Liabilitas), salah satunya aktivitas pengelolaan dikenal dengan manajemen likuiditas.

Penjelasan tentang pentingnya manajemen likuiditas pada Bank Syariah menurut Ismal (2010a) :

"In the practice, one of theultimate objectives of liquidity management is maintaining asset-liability balances. Hence, it manages funding and financing activities; forecasts of demand of funding and financing ; and maintains sufficient capacity (reserves) to fulfill financial obligations with the third parties. Under the global and open economic condition, the task to build a proper liquidity management becomes very imperative and challenging, unexceptionally for Islamic banks as new players in the banking industry. Actually, Islamic banks have unique characteristics of banking operations because in principle they have to comply with sharia principles. As such, setting up a liquidity management mechanism in this financial institution requires extra efforts and special attention. For example, dissimilar with the conventional banks which often disconnect the performance of financial and real sector, liquidity risk in Islamic banks might arise when business 
(realsector) is in downturn causing a failure to conduct a proper liquidity management (a balance asset and liability)."

Manajemen likuiditas Bank Syariah merupakan aktivitas yang sangat penting bagi keberlangsungan perusahaan maka dibentuk unit kerja yang bertanggung jawab atas pengelolaan likuiditas Bank Syariah yang disebut ALCO (Asset Liabilities Committee). Penjelasan peran ALCO menurut Ismal (2010b) adalah:

"Asset Liability Committee (ALCO) a risk management committee chaired by the President Director that functions as the central command of liquidity risk policies for all directorates and is supported by the internal supervisor committee."

Rasio keuangan menurut Ismal (2011:39) yang dapat digunakan untuk menganalisis likuiditas Bank Syariah dibagi menjadi 4 (empat) yaitu :

a) Rasio perbandingan antara Aset Lancar dengan Kewajiban Lancar

b) Rasio perbandingan antara Deposito dengan Pembiayaan Swasta

c) Rasio perbandingan antara Total Tiga Jenis Pembiayaan Bermasalah dengan Total Pembiayaan keseluruhan (NPL pada bank konvensional dan NPF pada bank Syariah)

d) Rasio perbandingan antara Total Pembiayaan dengan Total Simpanan (LDR pada bank konvensional dan FDR pada bank Syariah)

Tiga hal penting yang mempengaruhi likuiditas perbankan Syariah menurut Ismal (2009) dalam Ismal (2010b) disampaikan

"The first one is the rational depositors who are very sensitive with the movement of interest rate. The second one is the large portion of one-month time deposits which may imbalance the asset-liability equilibrium and the limitation of Islamic banks to arrange the optimal financing allocations. The last one is the macroeconomic factor particularly the increasing trend of interest rate which could tempt the rational depositors above to switch their deposits fromIslamic banks to the conventional banks."

Operasional Bank Syariah khususnya dalam manajemen likuiditas juga dipengaruhi faktor eksternal yaitu kondisi perekonomian Indonesia. Hal ini juga terjadi negara - negara lainnya sebagaimana disampaikan Siddiqi (2008)

"As financial institution, banks should manage the demand and supply of liquidity in an appropriate manner in order to safely run their business, 
maintain good relations with the stakeholders and avoid liquidity problem. The liquidity problems commonly happen because of failures in the management of funds or unfavorable economic conditionswhich lead to unpredictable liquidity withdrawals by the depositors.Indeed, maintaining a robust liquidity management is very challenging and difficult in a current competitive and open economic system with strong external influences and sensitive market players. The global financial crisis 2007-2008, for example, occurred because of the failures in derivatives markets which impacted the ability of banks to provide liquidity to the third parties."

Beberapa penelitian tentang likuiditas perbankan Syariah yaitu Sukmana dan Suryaningtyas (2016) yang membandingkan antara bank Syariah dengan bank konvensional, hasil penelitian menunjukkan bahwa terhadap pengaruh signifikan dan positif pada variabel CAR terhadap likuiditas bank Syariah, terhadap pengaruh signifikan dan negatif pada variabel ROA terhadap likuiditas bank Syariah sedangkan variabel NPF tidak signifikan mempengaruhi likuiditas bank Syariah. Penelitian faktor makroekonomi yang mempengaruhi likuiditas bank oleh Trenca et. al. (2015) menunjukkan bahwa bahwa faktor makroekonomi yaitu Tingkat Inflasi, Defisit Public, Tingkat Pengangguran, GDP (Gross Domestic Product) dan Rasio Likuiditas periode sebelumnya adalah berpengaruh terhadap likuiditas bank.

Waemustafa dan Sukri (2016) meneliti perbandingan tentang faktor yang mempengaruhi likuiditas bank Syariah dengan bank konvensional, menunjukkan bahwa faktor eksternal atau variabel makroekonomi Tingkat Pengembalian Bank Syariah (Islamic Rate) dan GDP tidak signifikan mempengaruhi likuiditas bank Syariah, sedangkan variabel Output Gap dan Inflasi berpengaruh signifikan dan negatif terhadap risiko likuiditas Bank Syariah. Variabel spesifik bank Syariah yaitu NPF, LEV, RSEC, REGCAP (capital / total assets), FLP, Finance, RWA, ISCON, DER, EM, Liquid (securities / total asset), MGT (earning assets / total assets), ROA, Ln Size (Ln total assets) memberikan pengaruh signifikan negatif terhadap risiko likuiditas Bank Syariah.

Berdasarkan penjelasan peran dan faktor - faktor yang mempengaruhi likuiditas perbankan Syariah berdasarkan penelitian jurnal nasional dan internasional, maka peneliti ingin mengetahui tingkat signifikansi faktor - faktor 
yang mempengaruhi Likuiditas Bank Syariah, baik secara internal Bank Syariah dan secara eksternal yaitu kondisi makroekonomi.

Hipotesis dari peneliti bahwa variabel bebas berupa faktor eksternal dan internal perbankan Syariah secara keseluruhan berpengaruh signifikan terhadap likuditas perbankan Syariah. Dimana variabel NPF, INF dan D07 memberikan pengaruh negatif dan variabel EK dan RRD memberikan pengaruh positif terhadap likuditas perbankan Syariah.

\section{METODE PENELITIAN}

Obyek penelitian adalah data Bank Syariah (Bank Umum Syariah dan Unit Usaha Syariah) di Indonesia. Penelitian menggunakan periode pengamatan dari Januari 2003 hingga Oktober 2015, dengan jenis data secara bulanan. Penelitian menggunakan 154 waktu amatan $(\mathrm{N}=154)$. Jenis data yang digunakan adalah data sekunder yang disusun secara time series (runtun nyawaktu).

Metode pengumpulan data yang digunakan adalah dengan studi dokumentasi. Studi dokumentasi adalah pengumpulan data yang dilakukan dengan kategori dan klasifikasi bahan - bahan tertulis yang berhubungan dengan masalah penelitian.

Data - data penelitian untuk faktor internal Bank Syariah yang dikumpulkan adalah, Financing to Deposit Ratio (FDR) sebagai variabel dependen dan variabel independen - nya adalah NPF, Rate of Return Deposito (menggunakan data Bank Pemerintah sebagai proksi Imbal Hasil Deposito Bank Syariah) yang terdapat di Indonesia selama periode Januari 2003 - Oktober 2015. Sumber data yang digunakan dalam penelitian ini dalam penelitian ini diperoleh dari Statistik Perbankan Syariah yang diterbitkan oleh Bank Indonesia. Selain itu juga didownload melalui situs resmi Bank Indonesia yaitu www.bi.go.id.

Pemilihan variabel FDR berdasarkan penjelasan Ismal (2011:39) tentang rasio keuangan yang merupakan indikator likuiditas bank Syariah. Pemilihan variabel NPF berdasarkan penelitian Sukmana dan Suryaningtyas (2016). Pemilihan variabel tingkat pendapatan Deposito (RRD) berdasarkan penjelasan Ismal (2009) tentang faktor yang mempengaruhi likuiditas bank Syariah. 
Pemilihan variabel makroekonomi sebagai variabel atau faktor eksternal perbankan Syariah didasarkan kepada penelitian Trenca et. al (2015). Data - data penelitian untuk faktor eksternal Bank Syariah, yang dikumpulkan adalah Tingkat Inflasi di Indonesia selama periode Januari 2003 - Oktober 2015. Sumber data yang digunakan dalam penelitian ini dalam penelitian ini diperoleh dari Statistik Ekonomi dan Keuangan Indonesia, yang diterbitkan oleh Bank Indonesia. Selain itu juga di-download melalui situs resmi Bank Indonesia yaitu www.bi.go.id.

Data - data penelitian untuk faktor eksternal Bank Syariah, yang dikumpulkan adalah Kinerja Ekonomi ( IPI (Indeks Produksi Indonesia) sebagai proksi Pertumbuhan Ekonomi atau Kinerja Perekonomian yang dapat diketahui perkembangannya melalui data bulanan) di Indonesia selama periode Januari 2003 - Oktober 2015. Sumber data yang digunakan dalam penelitian ini dalam penelitian ini diperoleh dari Badan Pusat Statistik Indonesia, yang diterbitkan oleh Bank Indonesia. Selain itu juga di-download melalui situs resmi Badan Pusat Statistik yaitu www.bps.go.id.

Untuk data dummy, tentang terjadinya krisis keuangan global (D07), ditetapkan dan didukung dari literatur yang membahas terjadinya krisis keuangan global yang dimulai bulan Agustus tahun 2007 berdasarkan pendapat Basri dan Munandar (2009:539) yang membahas tentang dampak terjadinya krisis keuangan global terhadap perekonomian Indonesia.

Semua data - data yang diperoleh tersebut dikelompokkan dalam tabel - tabel dan selanjutnya diolah dengan menggunakan perangkat Eviews 6.1.

Adapun model teknik analisis penelitian ini ditunjukkan pada persamaan 1.1

$$
\mathrm{FDR}=\mathrm{b} 1 \mathrm{NPF}+\mathrm{b} 2 \mathrm{RRD}+\mathrm{b} 3 \mathrm{INF}+\mathrm{b} 4 \mathrm{EK}+\mathrm{b} 5 \mathrm{D} 07
$$

dimana :

FDR : (Financing to Deposit Ratio) pada periode $\mathrm{t}$

NPF : Non Performing Financing periode $\mathrm{t}$

RRD : Rate of Return (Deposito) pada periode $\mathrm{t}$

EK : Kinerja Ekonomi pada periode $\mathrm{t}$

INF : Tingkat Inflasi pada periode $\mathrm{t}$

D07 : dummy terjadinya krisis keuangan global pada periode $\mathrm{t}$ 
Besarnya koefisien dari masing - masing variabel independen ditunjukkan dengan b1, b2, b3, b4, dan b5.

\section{Uji Stasioneritas}

Metode yang digunakan dalam pengujian unit akar ini adalah uji Augmented Dickey - Fuller (ADF) dan uji Philips - Perron (PP). Sedangkan nilai kritisnya digunakan kriteria nilai kritis yang diungkapkan oleh MacKinnon. Jika nilai t$\mathrm{ADF}$ atau t-PP lebih luas dari nilai kritis yang dipersyaratkan maka data itu statis atau tidak memiliki akar unit (Faiz, $2010: 227)$.

\section{Uji Kointegrasi}

Definisi kointegrasi ini menjadi penting karena dengan konsep ini dapat diamati hubungan ekuilibrium jangka panjang (long - run ekuilibrium) dari variabel variabel yang tidak stasioner (karena mengandung trend) (Rosadi, 2012 : 200). Salah satu pendekatan yang dapat digunakan dalam uji kointegrasi adalah metode Johansen (Ajija, 2011 : 190).

Dalam pengujian reduce rank, Johansen menggunakan dua pengujian statistik yang berbeda yaitu trace test ( $\lambda$ trace) dan maximum eigenvalue test $(\lambda$ max). Trace test menguji $\mathrm{H}_{0}$ pada persamaan kointegrasi $\tau$ sebagai kointegrasi alternatif dari persamaan kointegrasi $\mathrm{k}$, k merupakan bilangan variabel endogen untuk $\tau=0,1, \ldots, \mathrm{k}-1$. Pengujian $\mathrm{H}_{0}$ melalui trace test dapat ditunjukkan melalui persamaan berikut :

$L R_{\text {trace }}\langle\tau \mid k\rangle=-T \sum_{i=r+1}^{k} \log \left(1-\lambda_{\mathrm{i}}\right)$

Dimana $\lambda_{\mathrm{i}}$ merupakan eigenvalue terbesar dari matriks П. Maksimum eigenvalue test menguji $\mathrm{H}_{0}$ pada persamaan kointegrasi $\tau$ sebagai kointegrasi alternatif dari persamaan kointegrasi $\mathrm{k}+1$. Pengujian $\mathrm{H}_{0}$ melalui maximum eigenvalue test dapat ditunjukkan pada persamaan berikut :

$L R_{\max }\langle\tau \mid k+1\rangle=-T \log \left(\log \left(1-\lambda_{\mathrm{r}+1}\right)\right.$

$L R_{\max }\langle\tau \mid k+1\rangle=L R_{\text {trace }}\langle\tau \mid k\rangle-L R_{\text {trace }}\langle\tau+1 \mid k\rangle$

Dimana : $\tau=0,1, \ldots, \mathrm{k}-1$. 
Permasalahan utama dalam data time series adalah adanya autokorelasi. Untuk mengatasi permasalahan ini maka harus digunakan panjang lag optimal yang diperoleh dari pengujian lag optimal. Penentuan lag optimal dalam penelitian ini didasarkan pada lag terpendek menurut Schwarz Information Criterion (SCI). Menurut Gujarati SIC memberikan timbangan yang lebih baik daripada AIC karena SC memberi timbangan lebih besar dan penalti lebih terhadap penambahan variabel (Faiz, $2010: 227$ ).

\section{HASIL DAN PEMBAHASAN}

\section{Uji Stasioneritas Data}

Tahap awal menguji data time series (runtut waktu), harus diuji dengan melakukan uji unit root atau uji Stasioneritas data dengan menggunakan Augmented Dickey Fuller (ADF) dan Philips Perron (PP). Di dalam uji stasioneritas data time series, menggunakan hipotesis apabila $\mathrm{H}_{0}$ menunjukkan terdapat unit root dan $\mathrm{H}_{1}$ menunjukkan tidak terdapat unit root. Adapun hasil uji stasioneritas disampaikan pada tabel 1

Tabel 1 : Hasil Uji Stasioneritas ADF dan PP

\begin{tabular}{|c|c|c|c|c|c|c|c|c|}
\hline \multirow{4}{*}{ No. } & \multirow{4}{*}{ Variabel } & \multirow{4}{*}{$\begin{array}{c}\text { Kode } \\
\text { Variabel }\end{array}$} & \multicolumn{4}{|c|}{ ADF } & \multicolumn{2}{|c|}{ PP } \\
\hline & & & \multicolumn{2}{|r|}{ Level } & \multicolumn{2}{|r|}{1 st Diference } & \multirow{2}{*}{$\frac{\text { Level }}{\text { Intercept }}$} & \multirow{2}{*}{$\frac{1 \text { st Diference }}{\text { Intercept }}$} \\
\hline & & & Lag & Intercept & Lag & Intercept & & \\
\hline & & & & $\begin{array}{c}\text { Trend \& } \\
\text { Intercept }\end{array}$ & & $\begin{array}{c}\text { Trend \& } \\
\text { Intercept }\end{array}$ & $\begin{array}{c}\text { Trend \& } \\
\text { Intercept }\end{array}$ & $\begin{array}{c}\text { Trend \& } \\
\text { Intercept }\end{array}$ \\
\hline \multirow[t]{2}{*}{1} & $\begin{array}{l}\text { Financing } \\
\text { to Deposit } \\
\text { Ratio }\end{array}$ & $\mathrm{fdr}$ & 0 & $-3,153645 * *$ & 0 & $-11,10485 * * *$ & $-3,153645 * *$ & $-11,05821 * * *$ \\
\hline & & & 0 & $-3,521597 * *$ & 0 & $-11,06690 * * *$ & $-3,753795 * *$ & $-11,01453 * * *$ \\
\hline \multirow[t]{2}{*}{2} & $\begin{array}{c}\text { Non } \\
\text { Performing } \\
\text { Financing }\end{array}$ & npf & 0 & $-3491912 * * *$ & o & $-14,83732 * * *$ & $-3,330440 * *$ & $-14,87633 * * *$ \\
\hline & & & 0 & $-3,515425 * *$ & o & $-14,78935 * * *$ & $-3,357943 *$ & $-14,82772 * * *$ \\
\hline \multirow[t]{2}{*}{3} & $\begin{array}{c}\text { Rate of } \\
\text { Return } \\
\text { (Deposito) }\end{array}$ & rrd & 2 & $-4,929392 * * *$ & 1 & $-2,646023 *$ & $-3,125062 * *$ & $-3,596511 *$ \\
\hline & & & 2 & $-5,385348 * * *$ & 1 & $-2,628894$ & $-2,973977$ & $-3,665345 * *$ \\
\hline \multirow[t]{2}{*}{4} & Inflasi & $\inf$ & 1 & $-2,798542 *$ & 0 & $-10,12691 * * *$ & $-2,721475 *$ & $-10,08177 * * *$ \\
\hline & & & 1 & $-2,958077$ & 0 & $-10,09181 * * *$ & $-2,832209$ & $-10,04566 * * *$ \\
\hline \multirow[t]{2}{*}{5} & $\begin{array}{l}\text { Kinerja } \\
\text { Ekonomi }\end{array}$ & Inek & 1 & $-2,823778 *$ & 0 & $-17,22181 * * *$ & $-3,660758 * * *$ & $-18,46081 * * *$ \\
\hline & & & 1 & $-2,817775$ & 0 & $-17,16577 * * *$ & $-3,651645^{* * *}$ & $-18,39866 * * *$ \\
\hline \multirow[t]{2}{*}{6} & Dummy 07 & d07 & 0 & $-1,338317$ & 0 & $-12,32883 * * *$ & $-1,338317$ & $-12,32883 * * *$ \\
\hline & & & 0 & $-1,661489$ & 0 & $-12,30922 * * *$ & $-1,688864$ & $-12,30922 * * *$ \\
\hline
\end{tabular}

Keterangan : * Significant $10 \% * *$ Significant $5 \% * * *$ Significant $1 \%$

Sumber : eviews 6.1 yang diolah 
Berdasarkan tabel 1, uji stasioneritas dengan menggunakan metode ADF pada tingkat level intercept. Variabel dinyatakan tidak terdapat unit root (akar unit) apabila nilai t-ADF atau t-PP lebih luas dari nilai kritis yang dipersyaratkan Mackinnon Critical Value dan sebaliknya. Adapun keterangan hasil uji stasioneritas adalah sebagai berikut :

a. Variabel FDR dinyatakan signifikan tidak terdapat unit root pada tingkat $\alpha$ $=5 \%$

b. Variabel NPF dinyatakan signifikan tidak terdapat unit root pada tingkat $\alpha$ $=1 \%$

c. Variabel RRD dinyatakan signifikan tidak terdapat unit root pada tingkat $\alpha$ $=5 \%$

d. Variabel INF dinyatakan signifikan tidak terdapat unit root pada tingkat $\alpha$ $=1 \%$

e. Variabel LNEK dinyatakan signifikan tidak terdapat unit root pada tingkat $\alpha=1 \%$

f. Variabel D07 dinyatakan signifikan terdapat unit root

\section{Uji Kointegrasi}

Berdasarkan hasil uji stasioneritas yang ditunjukkan oleh Tabel 1 diketahui bahwa data D07 (Dummy Krisis Keuangan Global) adalah stasioner di tingkat first different, maka kelima data lainnya (FDR, NPF, RRD, INF, EK) harus dirubah terlebih dahulu ke bentuk first differentnya.Hal ini berdasarkan Gujarati (2012:453) dinyatakan bahwa apabila sebuah time series memiliki sebuah unit root (unit akar / tidak stasioner), turunan pertama dalam time series seperti ini adalah stasioner.

Uji kointegrasi diawali dengan penentuan Lag Lenght dan Uji Kausalitas Granger (hasil terlampir). Uji Uji kointegrasi memberikan hasil yang dapat dianalisis sebagai bentuk bahwa diantara variabel dependent dengan variabel independent menunjukkan adanya hubungan jangka panjang, atau keseimbangan, antara kedua itu, sebagaimana terdapat pada penjelasan Gujarati (2012:458). Dan disampaikan Gujarati (2012:459), Teori Reprentasi Granger, menjelaskan bahwa 
apabila dua variabel $\mathrm{x}$ dan $\mathrm{y}$ adalah kointegrasi, hubungan antara keduanya bisa dinyatakan ECM (Error Correction Model), yang mengoreksi untuk keadaan keseimbangan.

Tabel 2 : Hasil Uji Cointegrasi

\begin{tabular}{|c|c|c|c|c|c|c|}
\hline \multirow{2}{*}{ Model } & \multirow{2}{*}{$\begin{array}{c}\text { Null } \\
\text { Hypothesi }\end{array}$} & Trace & 0.05 & Max-Eigen & 0.05 & \multirow{2}{*}{ Result } \\
\hline & & Statistic & Critical Value & Statistic & Critical Value & \\
\hline $\mathrm{r} \leq 0$ & 0,237850 & 111,4187 & 103,8473 & 40,74170 & 40,95680 & \multirow{6}{*}{$\begin{array}{c}\text { TE indicates } 1 \\
\text { cointegration and } \\
\text { ME indicates no } \\
\text { cointegration } \\
\text { with equation at } \\
\alpha=5 \%\end{array}$} \\
\hline $\mathrm{r} \leq 1$ & 0,184595 & 70,67697 & 76,97277 & 30,61054 & 34,80587 & \\
\hline $\mathrm{r} \leq 2$ & 0,126158 & 40,06643 & 54,07904 & 20,22835 & 28,58808 & \\
\hline $\mathrm{r} \leq 3$ & 0,067615 & 19,83808 & 35,19275 & 10,50143 & 22,29962 & \\
\hline $\mathrm{r} \leq 4$ & 0,035966 & 9,336655 & 20,26184 & 5,494299 & 15,89210 & \\
\hline$r \leq 5$ & 0,025290 & 3842356 & 9,164546 & 3,842356 & 9,164546 & \\
\hline
\end{tabular}

Berdasarkan hasil uji kointegrasi tabel 2 diketahui bahwa data Non Trend Intercept and Non Trend (2), menunjukkan ada 1 hubungan kointegrasi didasarkan nilai Trace Statistic ( $\lambda$ trace) lebih besar daripada nilai kritisnya pada tingkat signifikansi $\alpha=5 \%$, sehingga $\mathrm{H}_{0}$ yang menyatakan $\mathrm{r}=1$ atau terjadi kointegrasi diterima. Sedangkan Nilai Max Eigen Statistic ( $\lambda$ max) lebih kecil daripada nilai kritisnya pada tingkat signifikansi $\alpha=5 \%$, sehingga $\mathrm{H}_{1}$ yang menyatakan $r \neq 1$ atau tidak terjadi kointegrasi diterima. Dalam hal ini, peneliti akan menganalisis terjadinya kointegrasi berdasarkan nilai Trace Statistic yang menunjukkan terdapat kointegrasi.

Dari hasil uji kointergrasi ini dapat diketahui persamaan jangka panjang dari model tersebut :
DFDR $=-\quad$ 4,049132 DNPF + 8,174598 DRRD - 1,264403 DINF - 47,33272
DLNEK
t-std. error $\quad(1,27527)$
$(0,86601)$
$(19,9768)$
$(6,26996)$
$(1,46003)$

$$
+\quad 5,141163 \text { DD07 }
$$
$\mathrm{t}$ - statistik

t-std. error

$(4,07333)$

$\mathrm{t}$ - statistik

$(1,26215)$ 
Penjelasan persamaan jangka panjang dari hasil uji kointegrasi sebagai berikut :

a. Dari hasil uji kointegrasi didapatkan persamaan jangka panjang dimana NPF memiliki pengaruh sebesar $4,05 \%$ terhadap FDR, dengan nilai $\mathrm{t}$ - statistik $(3,17511)$ lebih besar dari nilai $\mathrm{t}$ - tabel tingkat signifikansi $10 \%$. Maka variabel NPF dapat menjelaskan persamaan jangka panjang. Tanda koefisien variabel NPF merupakan negatif, hal ini berarti bahwa NPF memiliki pengaruh negatif dalam persamaan jangka panjang. Maka berarti setiap kenaikan NPF sebesar $1 \%$ akan menurunkan FDR sebesar 4,05\%.

b. Pada uji kointegrasi RRD, didapatkan persamaan jangka panjang dimana RRD memiliki pengaruh sebesar 8,17 \% terhadap FDR, dengan nilai $\mathrm{t}$ - statistik (6,26996), lebih besar dari nilai $\mathrm{t}$ - tabel tingkat signifikansi $10 \%$. Maka variabel RRD dapat menjelaskan persamaan jangka panjang. Tanda koefisien variabel FIN merupakan positif, hal ini berarti bahwa RRD memiliki pengaruh positif dalam persamaan jangka panjang. Maka berarti setiap kenaikan RRD (Rate of Return(Deposito)) sebesar 1\% akan menaikkan Financial Deposit ratio sebesar $8,17 \%$.

c. Pada uji kointegrasi INF (Inflasi), didapatkan persamaan jangka panjang dimana INF memiliki pengaruh sebesar 1,26 \% terhadap FDR, dengan nilai t statistik $(1,46003)$, lebih kecil dari nilai $\mathrm{t}$ - tabel tingkat signifikansi $10 \%$. Maka variabel Tingkat inflasi tidak dapat menjelaskan persamaan jangka panjang. Tanda koefisien variabel FR merupakan negatif, hal ini berartibahwa INF memiliki pengaruh negatif dalam persamaan jangka panjang. Apabila signifikanmaka berarti setiap kenaikan INF sebesar 1\% akan menaikkan FDR sebesar $1,26 \%$.

d. Pada uji kointegrasi EK (Kinerja Ekonomi), didapatkan persamaan jangka panjang dimana EK memiliki pengaruh sebesar 47,33\% terhadap NPF, dengan nilai $\mathrm{t}$ - statistik $(2,36938)$, lebih besar dari nilai $\mathrm{t}$ - tabel tingkat signifikansi $10 \%$. Maka variabel EK dapat menjelaskan persamaan jangka panjang. Tanda koefisien variabel EK merupakan negatif, hal ini berarti bahwa kinerja ekonomi memiliki pengaruh negatif dalam persamaan jangka panjang. Maka 
berarti setiap kenaikan EK sebesar 1\% akan menurunkan FDR sebesar 47,33 $\%$.

e. Pada uji kointegrasi D07 yaitu variabel krisis global yang terjadi saat periode tersebut, didapatkan persamaan jangka panjang dimana D07 memiliki pengaruh sebesar 5,14 \% terhadap FDR, dengan nilai $\mathrm{t}$ - statistik $(1,26215)$, lebih kecil dari nilai $\mathrm{t}$ - tabel tingkat signifikansi $10 \%$. Maka variabel D07 tidak dapat menjelaskan persamaan jangka panjang. Tanda koefisien variabel D07 merupakan positif, hal berarti bahwa D07 memiliki pengaruh positif dalam persamaan jangka panjang. Apabila signifikanmaka berarti setiap terjadi D07 (Krisis Keuangan Global) akan menaikkan FDR sebesar 5,14 \%.

\section{Pembahasan Berdasarkan Uji Kointegrasi}

Berdasarkan hasil uji kointegrasi diketahui bahwa tanda koefisien variabel NPF merupakan negatif, hal berarti bahwa NPF memiliki pengaruh negatif terhadap FDR dalam persamaan jangka panjang. Maka berarti setiap kenaikan NPF sebesar 1\% akan menurunkan FDR sebesar 4,04 \%. Hal ini sesuai dengan Ismal (2011:83) bahwa risiko pembiayaan bank Syariah berupa NPF (Non Performing Financing), menghambat perkembangan pembiayaan apabila terus mengalami kenaikan. Dalam perspektif manajemen risiko likuiditas bank Syariah, kenaikan NPF akan mempengaruhi kemungkinan terjadinya permasalahan - permasalahan dalam risiko likuiditas. Dapat disimpulkan bahwa peningkatan NPF dapat menurunkan peningkatan pembiayaan sehingga berpeluang bank Syariah mengalami permasalahan likuiditas, dengan indikator menurunya tingkat FDR bank Syariah.

Berdasarkan hasil uji kointegrasi diketahui bahwa tanda koefisien variabel RRD merupakan positif, hal berarti bahwa RRD memiliki pengaruh positif terhadap FDR dalam persamaan jangka panjang. Maka berarti setiap kenaikan RRD (Rate of Return) sebesar 1\% akan menaikkan Financial Deposit ratio sebesar 8,17 \%. Menurut Ismal (2011:85), deposito Mudharabah merupakan simpanan yang favorit pada tahun 2000 - 2007 pada bank Syariah. Bagi bank Syariah semakin lama dilakukan penempatan dana pada deposito akan sesuai dengan perspektif pembiayaan jangka panjang yang dapat menghasilkan 
pendapatan yang lebih tinggi dibandingkan dana deposito ditempatkan pada jangka pendek.

Berdasarkan hasil uji kointegrasi diketahui bahwa tanda koefisien variabel EK merupakan negatif, hal berarti bahwa kinerja ekonomi memiliki pengaruh negatif dalam persamaan jangka panjang. Maka berarti setiap kenaikan EK sebesar $1 \%$ akan menurunkan FDR sebesar 47,33\%. Dalam hal ini dapat dijelaskan bahwa kondisi perekonomian yang baik dapat menurunkan FDR, hal ini disebabkan kondisi masyarakat yang sebagian besar berfikir secara rasional yaitu mengharapkan tingkat bagi hasil yang tinggi atas simpanan dananya di bank Syariah. Menurut Ismal (2011:87) pada kondisi perekonomian yang bagus dapat membuat masyarakat mengabaikan penempatan dana di bank Syariah dikarenakan terjadi peningkatan suku bunga dari investasi alternatif seperti bank (konvensional), bursa efek, pasar modal yang menawarkan imbal hasil yang lebih tinggi dibandingkan imbal hasil di bank Syariah. Sehingga dengan menurunnya penempatan dana di bank Syariah akan menyebabkan bank Syariah mengalami masalah likuiditas dan berpengaruh pada penyaluran pembiayaan.

Variabel INF (Inflasi) dan D07 (Dummy Krisis Keuangan Global) sebagai variabel independent dikarenakan tidak dapat mempengaruhi FDR (Financing to Deposit Ratio) sebagai variabel dependent, berdasarkan uji t (signifikansi). Maka untuk menambahkan analisis respon masing - masing variabel independent terhadap variabel dependent digunakan analisis IRF (Impulse Resposnse Function).

\section{Pembahasan Berdasarkan Impulse Response Function (IRF)}

Dari hasil estimasi dari Vector Error Correction Model diperoleh hasil Impulse Response Function dalam bentuk grafik yang ditunjukkan pada Gambar 1
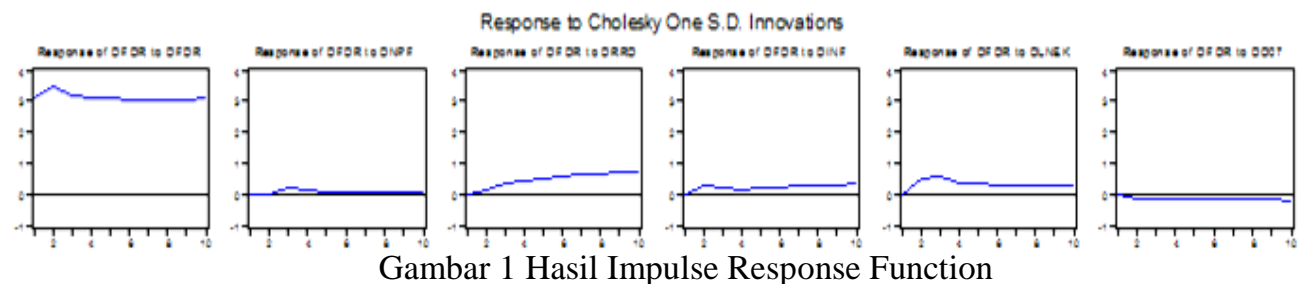

Gambar 1 Hasil Impulse Response Function

Sumber : Eviews 6.1. 
Dari hasil estimasi dari Vector Error Correction Model diperoleh hasil Impulse Response Function dalam bentuk angka yang menunjukkan respon variabel dependent dipengaruhi oleh variabel independent, yang ditunjukkan pada Tabel 3

Tabel 3 : Hasil Impulse Response Function

\begin{tabular}{|c|c|c|c|c|c|c|}
\hline \multicolumn{7}{|c|}{ Response of DFDR: } \\
\hline Period & DFDR & DNPF & DRRD & DINF & DLNEK & \multicolumn{1}{c|}{ DD07 } \\
\hline 1 & 3,102688 & 0,000000 & 0,000000 & 0,000000 & 0,000000 & 0,000000 \\
\hline 2 & 3,455978 & $-0,002735$ & 0,149415 & 0,240430 & 0,515314 & $-0,158186$ \\
\hline 3 & 3,170633 & 0,174442 & 0,364740 & 0,229491 & 0,525821 & $-0,139122$ \\
\hline 4 & 3,107612 & 0,140378 & 0,403185 & 0,137427 & 0,336983 & $-0,197449$ \\
\hline 5 & 3,070094 & 0,045855 & 0,460647 & 0,170905 & 0,305416 & $-0,199513$ \\
\hline 6 & 3,022177 & 0,036832 & 0,542313 & 0,215240 & 0,298731 & $-0,181320$ \\
\hline 7 & 3,014367 & 0,039873 & 0,601633 & 0,232596 & 0,262218 & $-0,187968$ \\
\hline 8 & 3,026813 & 0,033797 & 0,645667 & 0,256855 & 0,250080 & $-0,196954$ \\
\hline 9 & 3,044334 & 0,040624 & 0,685193 & 0,284975 & 0,252419 & $-0,199741$ \\
\hline 10 & 3,072504 & 0,056263 & 0,714484 & 0,308348 & 0,256385 & $-0,205394$ \\
\hline
\end{tabular}

Sumber : Eviews 6.1.

Adapun analisis respon variabel dependent dipengaruhi oleh variabel independent berdasarkan Uji Impulse Response Function sebagai berikut :

a. Gambar 1 dengan judul "Response of DFDR to DNPF" dan Tabel 3 Respon variabel Financing to Deposit Ratio (FDR) akibat adanya shock pada variabel Non Performing Financing (NPF). Respon yang ditunjukkan adalah respon yang positif. Hal ini menunjukan bahwa NPF pada bank syariah mengalami kenaikan dan akan menyebabkan FDR meningkat. Periode ketiga menjadi puncak dari respon FDR terhadap shock NPF secara positif yaitu sebesar 0,17\%. Namun nilai respon FDR terhadap NPF tidak terlalu tinggi dikarenakan nilainya tidak mencapai $0,5 \%$, sekalipun nilainya positif.

b. Gambar 1 dengan judul "Response of DFDR to DRRD" dan Tabel 3 Respon yang diberikan oleh variabel Financing to Deposit Ratio(FDR) terhadapshock Rate of Return (Deposito)/(RRD) adalah positif. Hal ini menunjukkan ketika RRD mengalami peningkatan dan akan menyebabkan FDR mengalami kenaikan. Dari periode awal,shock yang diberikan oleh RRD terus mengalami kenaikan hingga pada akhir periode menunjukan kenaikan puncak yang tertinggi dengan nilai mencapai $0,7 \%$. Nilai shock RRD merupakan tertinggi 
dibandingkan variabel independent yang lain (NPF, INF, EK dan D07) mencapai $0,5 \%$.

c. Gambar 1 dengan judul "Response of DFDR to DINF" dan Tabel 3 Respon yang diberikan oleh variabel Financing to Deposit Ratio (FDR) terhadapshock Inflasi (INF) adalah positif Hal ini menunjukkan ketika INF mengalami peningkatan dan akan menyebabkan FDR mengalami kenaikan. Respon positif FRD terhadap shock INF mengalami fluktuasi, dimana pada periode ke 4 (empat) merupakan periode nilai respon positif terendah sebesar $0,13 \%$ dan pada periode akhir merupakan puncak yang tertinggi sebesar 0,3\%. Namun nilai respon FDR terhadap shock INF tidak terlalu tinggi dikarenakan nilainya tidak mencapai $0,5 \%$, sekalipun nilainya positif.

d. Gambar 1 dengan judul "Response of DFDR to DLNEK" dan Tabel 3 Respon yang diberikan oleh variabel Financing to Deposit Ratio (FDR) terhadap shock Kinerja Ekonomi (EK) adalah positif. Hal ini menunjukkan ketika shockEK mengalami peningkatan dan akan menyebabkan FDR mengalami kenaikan.Dari periode awal hingga periode kedua,shock yang diberikan oleh EK mengalami puncak tertinggi dengan nilai mencapai 0,5\%. Penurunan shock terjadi dimulai periode ke 4 (empat) sebesar $0,33 \%$ dan mencapai titik terendah shock EK pada periode ke 8 (delapan) sebesar 0,25\%, kemudian terjadi peningkatan sekalipun tidak terlalu tinggi.

e. Gambar 1 dengan judul "Response of DFDR to DDO7” dan Tabel 1.3.: Respon yang diberikan oleh variabel Financing to Deposit Ratio(FDR) terhadapshockDummy Krisis Keuangan Global (D07) adalah negatif. Hal ini menunjukkan ketika shockD07 mengalami peningkatan dan akan menyebabkan FDR mengalami penurunan. Respon negatifif FRD terhadap shock D07 mengalami fluktuasi, dimana pada periode awal dan periode kedua terjadi penurunan sebesar $0,15 \%$ dan $0,13 \%$. Kemudian terjadi peningkatan shock D07 dari periode ke 4 (empat) dan ke 5 (lima) sebesar 0,19\% dan 0,20\%, namun menurun pada periode 6 (enam) sebesar 0,18\%. Peningkatan shock D07 dimulai kembali dari periode ke 7 (tujuh) sampai dengan periode akhir sebesar 
0,21\%. Namun nilai respon FDR terhadap shock D07 tidak terlalu tinggi dikarenakan nilainya tidak mencapai $0,5 \%$.

\section{PENUTUP}

FDR (Financing to Deposit Ratio) digunakan peneliti sebagai indikator likuiditas bank Syariah, berdasarkan hasil uji Kointegrasi (hubungan jangka panjang) antara FDR sebagai variabel dependent dengan variabel independent (NPF, RRD, INF, EK, D07), disimpulkan bahwa variabel yang memiliki pengaruh signifikan paling tinggi adalah EK (Kinerja Ekonomi) sedangkan yang paling rendah dalam signifikansi pengaruhnya adalah RRD dan NPF serta yang tidak signifikan berpengaruh adalah INF dan D07. Pengaruh setiap variabel independent (NPF, RRD, INF, EK, D07) terhadap variabel dependent (FDR) -nya berbeda - beda, antara lain EK dan NPF memiliki pengaruh signifikan negatif sedangkan RRD memiliki pengaruh signifikan positif, sedangkan meski tidak signifikan berpengaruh seperti pada variabel INF memiliki pengaruh negatif dan D07 memiliki pengaruh positif. Berdasarkan hasil uji kointegrasi dan dilengkapi dengan IRF (Impulse Response Function) maka disarankan kepada perbankan Syariah dalam mengelola likuiditasnya harus memperhatikan tingkat imbal hasil yang menarik bagi nasabahnya agar meningkatkan jumlah Dana Pihak Ketiga yang mendukung peningkatan likuiditas perbankan Syariah sehingga dapat dimanfaatkan untuk meningkatkan penyaluran pembiayaan kepada nasabah pembiayaan. Perbankan Syariah harus menghindari terjadinya pembiayaan bermasalah (NPF), dimana NPF menurunkan likuiditas perbankan Syariah. Pembiayaan perbankan Syariah juga harus mampu memprediksi kemampuan mengangsur nasabah yang ketika pada kondisi terjadi inflasi dan krisis ekonomi agar tidak mengalami pembiayaan bermasalah yang merugikan perbankan Syariah. 


\section{DAFTAR PUSTAKA}

Ajija, Shochrul Rohmatul dkk. 2011. Cara Cerdas Menguasai EViews. Jakarta : Penerbit Salemba Empat.

Basri, Faisal dan Haris Munandar. 2009. Landskap Ekonomi Indonesia : Kajian dan Renungan Terhadap Masalah - Masalah Struktural , Transformasi Baru, dan Prospek Perekonomian Indonesia. Jakarta : Kencana. Edisi Pertama. Cetakan Ke-1. Hlm. 539-544.

Gujarati, Damodar N dan Dawn C. Porter. 2012. Dasar - dasar Ekonometrika Basic Econometrics. Buku 2 Edisi 5. Jakarta : Penerbit Salemba Empat. America : Mc Graw Hill. Hlm. 428 - 456.

Ismal, Rifki. 2009. "Factors determining asset liability balancing', Journal of Islamic Banking and Finance, International Association of Islamic Banks, Vol. 26 No. 1.

Ismal, Rifki. 2010a. Assessment of liquidity management in Islamic banking industry. International Journal of Islamic and Middle Eastern Finance and Management Vol. 3 No. 2, 2010 pp. 147-167. (C) Emerald Group Publishing Limited 1753-8394. DOI 10.1108/17538391011054381

Ismal, Rifki. 2010b. Strengthening and improving the liquidity management in Islamic banking. Humanomics Vol. 26 No. 1, 2010 pp. 18-35. (C) Emerald Group Publishing Limited 0828-8666. DOI 10.1108/08288661011024977

Ismal, Rifki. 2011. The Indonesian Islamic Banking Theory and Practices. Gramata Publishing.

Ridlwan, A. A. (2016). Implementasi Akad Muzara'ah Pada Bank Syariah : Alternatif Akses Permodalan Sektor Pertanian. Iqtishoduna: Jurnal Ekonomi Islam, 7(1), 34-48.

Rosadi, Dedi, Dr. rer.net.. M.Sc. 2012. Ekonometrik dan Analisis Runtut Waktu Terapan. Yogyakarta : C.V. Andi Offset.

Sukmana, Raditya dan Sari Suryaningtyas. Determinants of Liquidity Risk in Indonesian Islamic and Conventional Banks. Al - Iqtishad : Jurnal Ilmu Ekonomi Syariah (Journal of Islamic Economics). Volume 8 (2), July 2016 P-ISSN: 2087-135X; E-ISSN: 2407-8654 Page 187 - 200.

Siddiqi, N. 2008. "Current Financial Crisis and Islamic economics", lecture paper in the long distance IDB courses in Islamic Banking and Finance.

Trenca, Ioan, Nicolae Petria and Emilia Anuta Corovei. 2015. Impact Macroeconomic Variables Upon The Banking System Liquidity. Procedia Economics and Finance 32 (2015) 1170 - 1177.

Undang - Undang Republik Indonesia Nomor 21 Tahun 2008 Tentang Perbankan Syariah 
Waemustafa, Waeibrorheem and Suriani Sukri. 2016. Systematic and Unsystematic Risk Determinants of Liquidity Risk Between Islamic and Conventional Banks. International Journal of Economics and Financial Issues. Vol 6 Issue 4.

\section{Sumber Dana Hibah Penelitian}

Penelitian berjudul "Analisis Faktor Eksternal dan Internal Perbankan terhadap Likuiditas Perbankan Syariah di Indonesia Periode Januari 2003 -

Oktober 2015" didukung dengan pendanaan dari Research Grant oleh Fakultas Ekonomi dan Bisnis Universitas Airlangga. 